\title{
Logistics 4.0: Do we have professionals prepared from an Education 4.0?
}

\author{
Carlos Alberto Schettini Pinto \\ Centro Federal de Educação Tecnológica Celso Suckow da Fonseca.
}

\begin{abstract}
With the advent of Industry 4.0, from 2011, it is clear that many areas had to adapt to the changes that came with the 4th Industrial Revolution. Having professionals prepared for the characteristics inherent to this new situation becomes a sine quae non for this highly connected and globalized environment. However, generations $\mathrm{X}, \mathrm{Y}$ and Alpha are quite collimated with these new technologies since they are born in digital environments and have, from an early age, access to technologies. However, people from older generations, if they are not immersed and interested in the continuity of digital learning, end up becoming digitally illiterate and unable to act in technologically active environments. Thus, this article asks, do we have professionals prepared for education 4.0? In addition, it presents a flow to be adopted in any academic area aimed at applying the characteristics of education 4.0.
\end{abstract}

Keywords: Industry 4.0; Logistics 4.0; Education 4.0; Management 4.0.

\section{Introduction}

Industry 4.0 allows men and machines to interact equally. Since the advent of the 3rd Industrial Revolution (Industry 3.0), many operations have been migrated to robotic machines, especially procedures in which the risk of serious accidents was notorious. It is a fact that these new interactions will generate a new intelligent workforce and will have significant effects on the nature of work. Thus, the integration of workers in an Industrial 4.0 System becomes a challenge to be thought of, since World 4.0 requires people with different skills, educational levels and broad culturais backgrounds. All, knowledgeable and adapted to New Information and Communication Technologies (NICT). In the understanding of Bitkom et al., (2016), Industry 4.0 was one of the terms used to describe the high-tech strategy promoted by the German government, and which has been implemented by its industry, covering a set of cutting-edge technologies related to the internet aiming to make production systems more flexible and collaborative.

Following the technological evolution, many experts point out that the advent of the $5 \mathrm{G}$ internet will be the evolutionary "Big Bang" of Industry 4.0.

In the evolutionary wake of the 4th Industrial Revolution, in this connected environment, obviously all areas would start to adapt to new technologies. It would be no different for the productive and operational area of logistics. It was to be expected that the term Logistics 4.0 would appear. The SEGS website (2021) highlights that, due to the changes that logistics 4.0 stimulates, new levels are reached. In this way, the entire process becomes much more assertive, intelligent and efficient, providing some of the benefits for companies that adhere to this innovation, such as the reduction of errors and losses of assets, fleet optimization and routing efficiency and significant improvement of operational efficiency.

Hence, the following question arises: Considering the technological growth coupled with Industry 4.0, how will human capital be prepared and qualified to be able to act efficiently with these technologies now available and those being developed? Are our universities and technical courses preparing new generations, as well as updating past generations, for this highly connected technological environment? In this tuning fork comes the need for an Education 4.0. This one brings in its mainstay the domain of learning by doing, of the maker culture, which walks "pair-by-step" with the DIY (Do It Yourself) vision. 
Carvalho Neto $(2018$, p. 31$)$ presents education 4.0 as "an advanced theoretical-practical approach to management and teaching in formal education that has been demonstrating, through evidence of scientific and technological research, its transformative and innovative potential for educational institutions".

However, for all this to work, there is a need for the existence of repositories for Knowledge Management $(\mathrm{KM})$, since there is a huge amount of data and information

that need to be processed in order to become knowledge, thus becoming a product bearer of value that generates competitive advantage.

The purpose of Knowledge Management is to capture knowledge and make it available to the organization, allowing for democratization and easier access to content. The school, as an organization, must realize that "the creation of organizational knowledge must be understood as a process that "organizationally" amplifies the knowledge created by individuals and crystallizes it at the group level through dialogue, discussion, sharing experience, making sense or community of practice." (TAKEUSHI AND NONAKA, 2008).

Given this scenario, this article aims to bring to light how Education 4.0 can and should be fundamental in the formation and specialization of human capital for Industry 4.0, in particular for Logistics 4.0.

The article is composed of the following structure: In Section 1, this Introduction. A literature review that consists of seeking theoretical bases of Industry 4.0, Logistics 4.0 and Education 4.0 is found in Section 2. The methodology applied in this study is described in Section 3. In Section 4, a Descriptive Phase and Analysis Commentary. And finally, a brief Conclusion, in Section 5.

\section{Literature Review \\ 2.1 Industry 4.0}

The term Industry 4.0 had its genesis at the fair in Hannover, Germany, in 2011 and was coined by Klauss Schwab. Also known as the 4th Industrial Revolution, it has been occupying spaces in various professional areas, generating the need for better educated and capable people to face the challenges of the connected world, generating a direct impact on productivity, as it provides significant increases in efficiency in use resources allowing for large-scale production in the production chain.Khatib and Barco (2021) point out that users are increasingly "buying and selling products online in small batches and expecting shipping delays of a few days or even hours". And they continue their thinking, citing the study by BMFB (2014) where they present as a result, that "the entire manufacturing industry, including its logistics, is changing to a more flexible and adaptable paradigm, giving way to Industry $4.0 "$.

It is important to realize the understanding of Acioli et al., (2021), with regard to disruptive technologies that are inherent to Industry 4.0, where they highlight

how artificial intelligence and big data, they can help companies plan supply chain processes. The COVID-19 pandemic situation, for example, has an impact on supply chains and, in this way, both the company and society are harmed. These technologies can contribute to the continuity of production chains in the midst of the COVID-19 pandemic or in other situations that could compromise the good performance of production chains (ACIOLI et al., 2021).

Khatib and Barco (2021) highlight four of the main enabling technologies that lie at the heart of Industry 4.0 and are presented in Table 1 and their interrelationship is shown in Figure 1. 
Table 1: Some Technologies from Industry 4.0

\begin{tabular}{|l|l|}
\hline Technology & Definition \\
\hline Big Data & $\begin{array}{l}\text { Analyzing large data allows, among other purposes, to identify } \\
\text { consumer needs, market trends or technical issues within the } \\
\text { production or even dissemination of knowledge. }\end{array}$ \\
\hline Wireless Connectivity & $\begin{array}{l}\text { A conectividade em equipamentos industriais e de logística é } \\
\text { usada para realizar a comunicação entre as máquinas, } \\
\text { coordenar a produção, monitorar, etc. }\end{array}$ \\
\hline $\begin{array}{l}\text { Wow Cost Sensor or } \\
\text { Networks Sensor }\end{array}$ & $\begin{array}{l}\text { Wireless networks that have a centralized control entity } \\
\text { capable of remotely controlling the activation and shutdown of } \\
\text { wireless communication interfaces, and a model capable of } \\
\text { making predictions for the presence or absence of associations } \\
\text { between a station and a network access point, for a period of } \\
\text { time, to then perform these actions and save energy without } \\
\text { impacting network capacity and coverage. }\end{array}$ \\
\hline Robotics & $\begin{array}{l}\text { With robotization and the creation of increasingly capable and } \\
\text { autonomous vehicles, the performance of very repetitive, } \\
\text { complex or risky tasks for human operators are being replaced } \\
\text { by machines, improving their working conditions and the } \\
\text { economic viability of industrial and logistical processes. }\end{array}$ \\
\hline
\end{tabular}

Source: Adapted from Khatib e Barco (2021)

Figure 1: Industry 4.0 technologies and their interdependence.

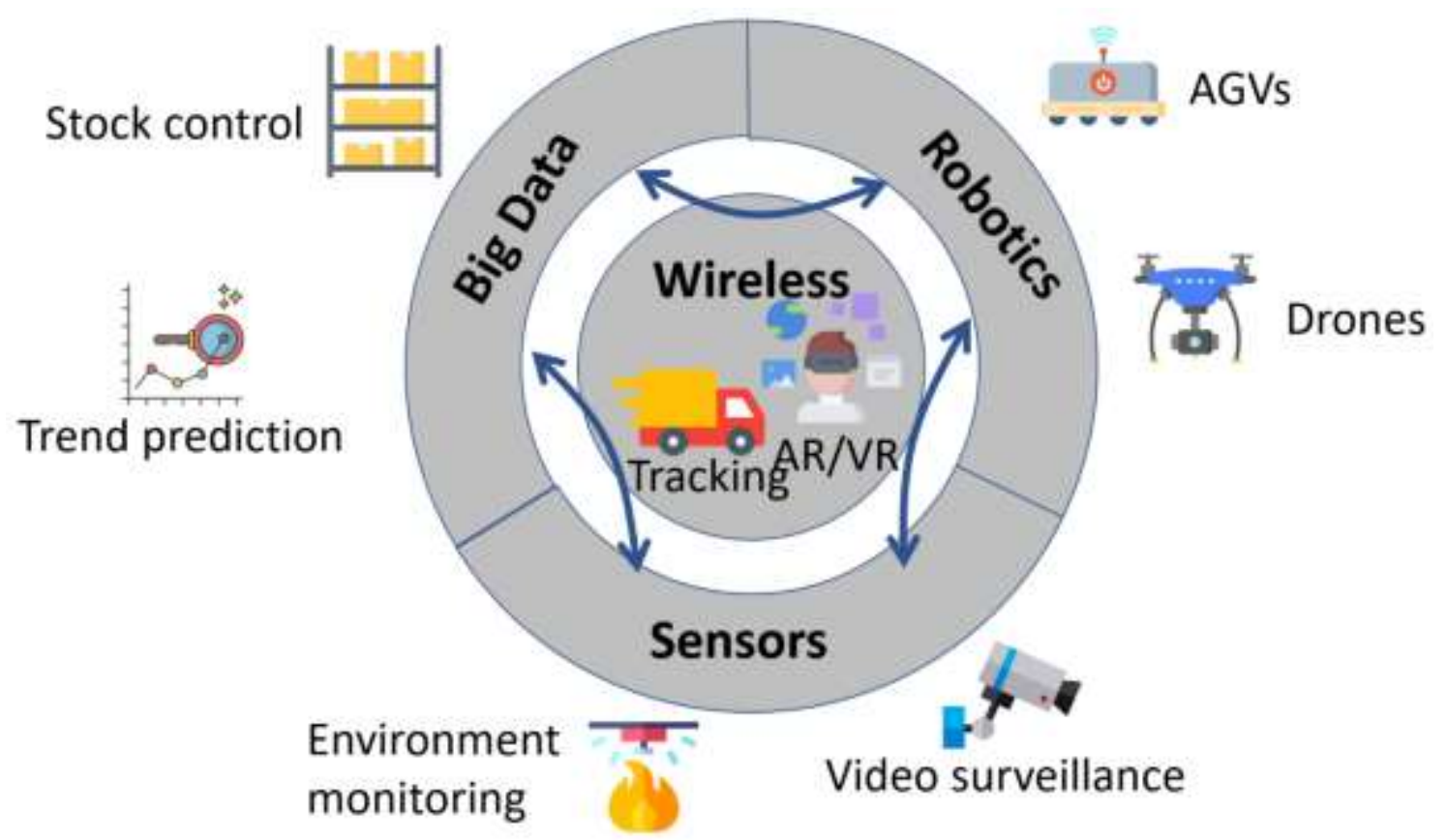

Source: Khatib e Barco (2021)

The authors highlight that Machine-Type Communications (MTC) are present in several devices and support a wide range of processes, giving rise to the Industrial Internet of Things (IIoT) (SISINNI et al., 2018). The use of 5G technology is evident, which is a technology that was mainly developed around vertical sectors, such as vehicular communications, entertainment or Industry 4.0. Ding et al., (2020) highlight the existence, in the area of intelligent logistics, of several scenarios where the use of 5G technology would be quite 
efficient, such as: freight, delivery, storage, among others. We realized, when checking Figure 1, the synergy that exists between Big Data, Robotics and Wireless Sensors technologies, having their communications interconnected by the wireless system, in this case, the $5 \mathrm{G}$.

The use of Wireless Sensor Networks (WSN) devices is essential since they have the ability to measure a series of parameters "on time" and decide, from predetermined responses, which actions to take, without the necessary human interference. Trstenjak and Cosic, (2017), mention that Industry 4.0 principles require a general change by digitizing and automating all parts of the company, along with the manufacturing process.

\subsection{Logistics 4.0}

The term logistics encompasses a series of functions inherent to an operating environment that deals with the displacement of the supply of production items to the flow of a product or service. In the entire process, from upstream to downstream, there is, directly or indirectly, the presence of logistics. Currently, the terminology has assumed the name of Supply Chain Management, which Bowersox et al., (2014) understand to consist of collaboration between companies to drive strategic positioning and improve operational efficiency.

This understanding is corroborated by Pinto (2020) who emphasizes that logistics meets a series of specific demands, whether in the delivery of inputs for production, or in the flow of this production, or in the provision of means for equipping fixed hospitals or hospitals. campaign. Similarly, this action is present and necessary to meet the operational logistical demands of industries, retail, general trade, construction, defense, among others.

Big Data-based systems comprise data-driven decision making (DDDM) in Logistics 4.0, and there are many studies that address the importance of Big Data in supply chain applications (WINKELHAUS and GROSSE, 2020).

Pinto et al., (2020) highlight that IoT and smart cities are establishing themselves within society and the use of informational flows of these technologies in line with existing flows in Supply Chain Management (GCS), in addition to capacity of sharing, common to Knowledge Management (KM) are important for the integration of a 4.0 environment, allowing the integration between the processes. There is no way to conceive isolated actions in a connected world, and the supply channel managers realized that without a qualified management of these processes, it will be impossible to meet the social demands that currently exist.

When we perceive the information listed in Figure 2, we realize that the flow of information travels through the entire network, from inputs (materials), through their processing, to delivery to the final consumer. All its processes are interconnected allowing a complete flow of information and actions. So, the flows need to be interconnected so that they can be fed back anywhere, speeding up procedures and allowing any course correction with more effective anticipation. This feedback must be continuous, infinitely and constantly improved (PINTO et al., 2020).

Figure 2: KM/SCM Information Flow Model

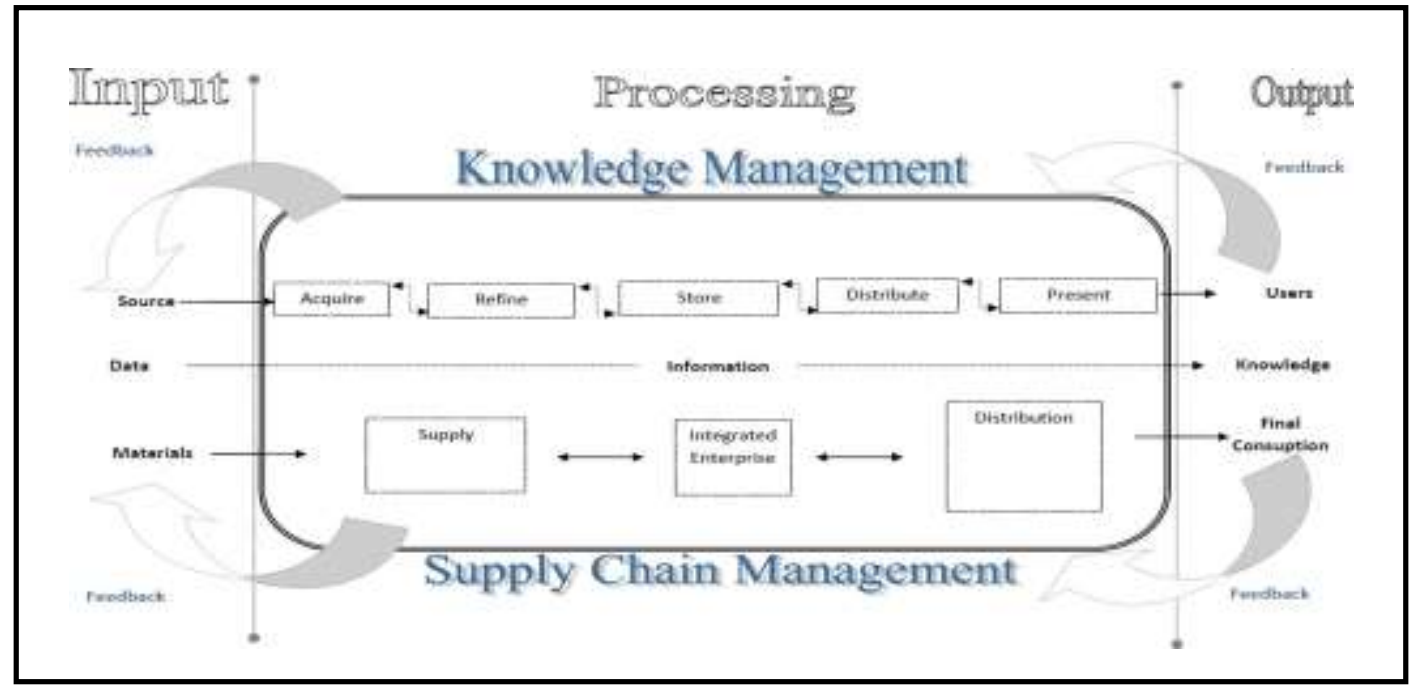

Source: The author 
Noteworthy is the study by Ilie-Zudor et al (2014) mentioning that, given the amount and extent of information, modern artificial intelligence methods can provide a substantial advantage for their abilities to collect and filter available information, identify phenomena of importance and provide decision support. In this way, the use of cutting-edge technologies will make all the difference in the digital transformation, having a direct impact on Industry 4.0.

When highlighting the use of Wireless Sensor Networks (WSN) in logistics, we highlight the RFID technology. This technology has the ability to monitor "on time", collecting data on detachment of equipment, products and even people, informing the control systems, providing accurate control and security. It also allows for real-time inventory control, highlighting the possibility of avoiding shortages and interruption of the resupply cycle. Satoh (2004) corroborates this understanding by stating that these systems, supported by multi-agents, perform location detection systems and guided intelligent vision systems (CHAO, 2005). Leitold et al., (2018) argue that, based on information from RFID, the Shop Floor Control (SFC) and optimization can also be performed by readers, from the provision of data that allow the estimation of duration tasks, how the production line is balanced, the effect of product changes, and providing real-time data for OEE (Overall Equipment Effectiveness) calculations.

When approaching the IoT technology in Logistics, it is important to understand that it is easy to use and very accessible, as it provides data from the supply chain processes, demonstrating and highlighting the existing flows for logistics operators, allowing, in an agile way the taking of efficient and effective decisions for the continuity of the logistic flows. When approaching Big Data in the Logistics environment, it has been recently explored in different contexts. Giannakis and Louis (2016) highlight its use in increasing the agility of SCM with Big Data and multi-agent-based systems. Zhong et al., (2016) highlight its use in the manufacturing sector. In the optimization of the green SCM, where care with hazardous materials and carbon emissions are considered, the understanding of Zhao et al. (2017) stands out. Lastly, Kache and Seuring (2017) present their understandings when dealing with the SCM information flow.

Currently, due to the data deluge, there has been a drastic increase in data and its filtering is necessary to obtain knowledge that bears the future that allows the generation of value for decision-making. As highlighted by Pinto (2019, p. 37):

From data to knowledge, there is the action of a subjective load and a contextualization that allows the generation of meaning. This allows data to be transformed into information. Then, with the addition of other information, greater and better contextualization, with the use of our perception (psychic apparatus), having a specific purpose, aiming at decision-making, there is the knowledge product. (PINTO, 2019, p.37).

Munshi and Mohamed (2017) and, Srinivasan and Swink (2018) highlight the speed of its propagation in the current corporate environment, noting that this complex scenario impels organizations to develop distinct data storage, processing and analysis capabilities to support the process of decision making.

\subsection{Education 4.0}

In a report on the Iscolapp blog, Prof. Dr. Cassiano Zeferino de Carvalho Neto, highlights that "In Education 4.0 what is seen is that it is not the media that makes the difference, but the people responsible for these innovations (emphasis added)." (ISCOLAPP, 2019).

Thus, it is important to emphasize that the media, NICT and informational means are important tools for the promotion and induction of learning by the student, but that, without the presence of the teacher, whether as a mediator, motivator or guide, it will be always fundamental for the balance of classroom teaching - virtual or real (face-to-face).Himmetoglu et al., (2020) emphasize that "Education 4.0 can be seen as a new paradigm that reinterprets concepts such as learning, student, teacher and school, according to the needs of Industry 4.0".

Fuertes et al., (2021) comment that a reality-oriented educational environment for Industry 4.0 needs to address a wide range of technologies, such as cloud data processing, digital twins, connectivity with protocol standards, passing by industrial cybersecurity measures, aimed at empowering people to occupy the functions of this new connected environment.

Suitable for the new Alpha, Z and Y generations, the availability of remote virtual laboratories and the use of augmented reality allow students to acquire practical knowledge and perform interactive teaching in a 
continuous and active manner (GRODOTZKI, et al., 2018; HERADIO et al., 2016). In this way, they end up using and getting to know existing technologies, that is, learning and experimenting in practice, which, according to Hernández-de-Menéndez et al., (2019) provide high practical academic benefits.

Figure 3 shows a framework of the Pyramid of Education 4.0. We realized that World 4.0, where several 4.0 agnomes originating from Industry 4.0 are inserted, demand, in order to be effective and efficient in their activities, the services of Education 4.0. In order to fulfill its main mission, which is to prepare and qualify people to assume work functions, Education 4.0 needs to follow an ascending path of preparation and availability of knowledge, as highlighted in the Education 4.0 Pyramid. This presents itself as a dynamic and sequential organism, where the infrastructure allows the necessary support so that teachers can stimulate the evolutionary capacities of students and, these, can become actors and protagonists of their actions. Finally, this process allows for the formation and stimulation of socio-emotional skills, extremely fundamental in this learning and knowledge environment. In this way, we realize that the "World 4.0" demands the services of Education 4.0, and this one checks in the organizational environment what will be the demands that will have to be met so that this evolutionary cycle of knowledge can be perpetuated.

Figure 3: Framework of Education 4.0 to Industry 4.0

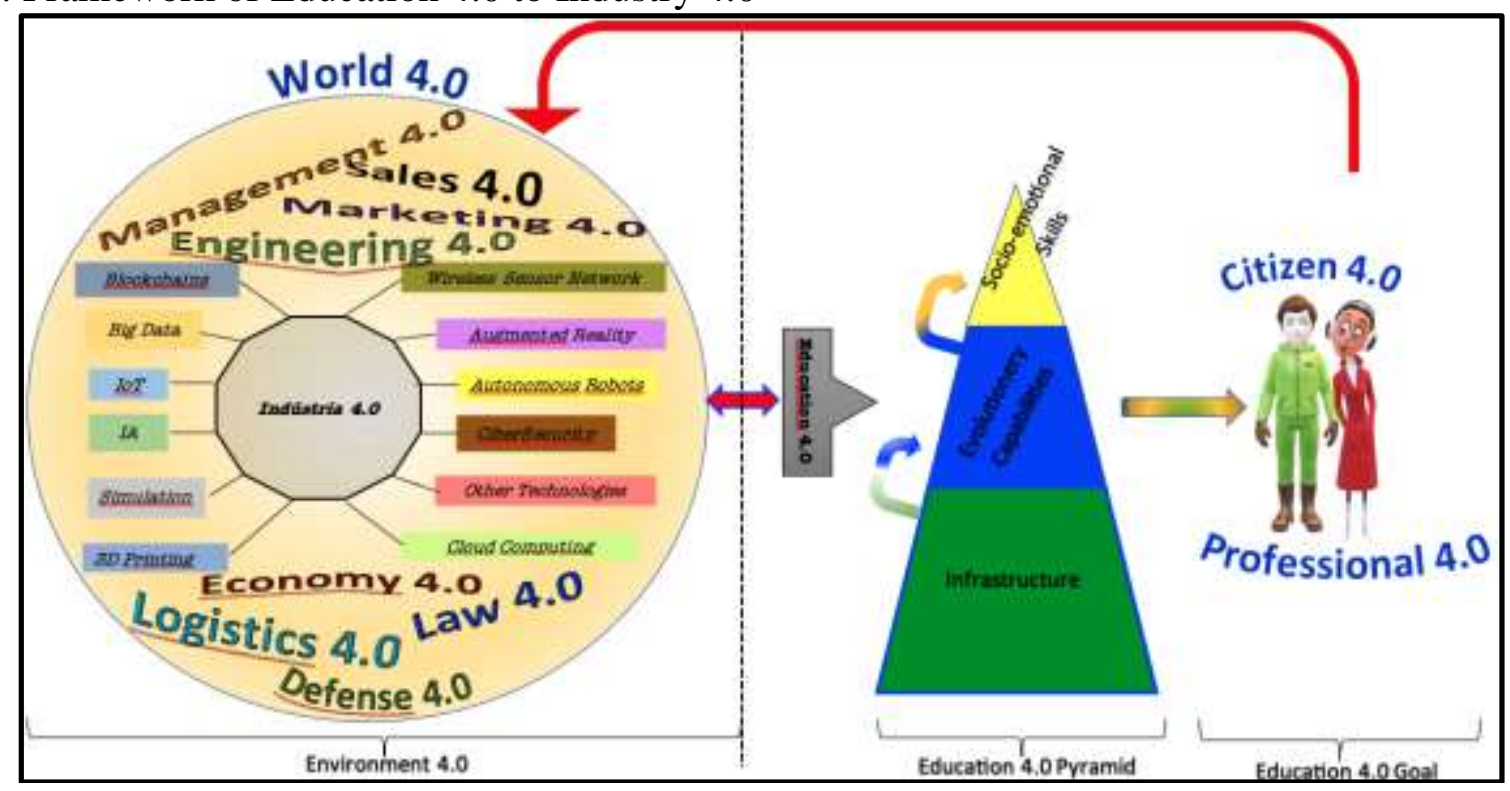

Source: The author

\section{Methodology}

The methodology used in this article was the bibliographic research of authors and their positions on Industry 4.0, Logistics 4.0 and Education 4.0. Based on these positions, the research focuses on the interrelationships between these three great fields of knowledge.

As a source, due to its scope and qualified content, the following research base was used: CAPES Periodicals (www.periodicos.capes.gov.br) using the following keywords: Industry 4.0, Logistics 4.0 and Education 4.0. Aiming at the refinement of the searches, searches combined with each other using the Boolean operator "and" in the keywords were adopted as procedural actions; Only articles and review articles were searched; the time range sought the journals published from 2017 to the present date. The consultation took place during the period from October 1st to October 25th, 2021.

In order to increase the refinement, the search was filtered by subjects related to areas of knowledge that were collimated with the research objectives. Subsequently, these articles were selected, firstly by reading the abstracts and, sequentially, by the constant in their introductions. As a penultimate step, the articles were completely read, separating those with added value. At the end of their reading, 25 articles were selected for effective research and support for the writing of this work. It is noteworthy that this content analysis aimed, mainly, to obtain updated ideas to support the study itself. Table 3 presents the responses obtained in the survey. 
Table 3: Flow of Bibliographic Research in Databases

\begin{tabular}{|c|c|c|c|c|}
\hline Keyword & Steps & Applied Filter & & Periodicals CAPES \\
\hline \multirow{6}{*}{ 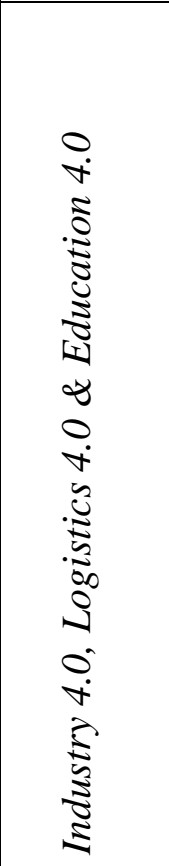 } & 1 & $\begin{array}{l}\text { Period from } \\
2017 \text { to } 2021\end{array}$ & & 1.333 \\
\hline & 2 & $\begin{array}{l}\text { Only Open } \\
\text { Articles }\end{array}$ & & 617 \\
\hline & 3 & By Subject & $\begin{array}{l}\text { - Engineering (236); } \\
\text { - Computer Science } \\
\text { (156); } \\
\text { - Decision Science (56). }\end{array}$ & 448 \\
\hline & 4 & $\begin{array}{l}\text { By Summary } \\
\text { Reading }\end{array}$ & & 157 \\
\hline & 5 & $\begin{array}{l}\text { By Reading } \\
\text { Introduction }\end{array}$ & & 79 \\
\hline & 6 & $\begin{array}{l}\text { Used } \\
\text { Articles }\end{array}$ & & 25 \\
\hline
\end{tabular}

Source: Author

In addition to the articles obtained from the two databases, some books and articles from other databases were used, as well as internets pages addressing issues related to the proposed themes, containing information that guided the research and substantiated the work in knowledge with added value.

\section{Descriptive Phase and Analysis Commentary}

After researching the sources of consultation, aiming to better support the studies and provide solid support, we move on to the descriptive phase with the presentation of the results of all the work carried out.

We realized that Industry 4.0 is an existence that meets the connected reality of new generations, especially those comprised by $\mathrm{Y}, \mathrm{Z}$ and Alpha. We live in a world in constant and accelerated change, with dynamic updates and, in most cases, non-linear. People are increasingly connected and dependent on gadgets, computers, electronics, the internet.

Homes, industries, smartphones, cars are all connected. We have most of the information at our fingertips, or even from a voice command. All these technologies are available for the most diverse forms of use and use. As we saw in Figure 3, all areas already have, linked to their terminology, the 4.0 suffix. In this way, it would be inconceivable for us not to have an education that would suit the evolution of the world. Its main function is to prepare people to enter the existing working environments which require qualified and specialized personnel in a certain area, knowledge or even function.

However, to reach a high level of expertise, it is initially up to the professors and the academic area to prepare for this challenge, evolving in the proposition of active methodological actions, in the change and organization of curricula through the approximation of labor areas, getting to know their demands and understanding the changes that must be carried out. In addition, understanding that generations undergo constant changes and teachers need to know them in order to prepare themselves in the most effective way that allows them to technologically dialogue with this target audience.

Teachers who do not seek to update themselves, not only in the concepts of their disciplines, but also in the ways of building and sharing knowledge, will be doomed to failure and stagnation. Knowing the new informational technologies and knowing how to use them will allow them to insert themselves in this advanced technological environment.

Realizing that work environments are constantly changing is also a key factor in proposing assessments and activities. As described in Table 2, companies in this new 4.0 environment look for proactive people, who know how to live and work in groups, who decide quickly and accurately, where critical and computational thinking is valued, autonomous learning is valued, collective and collaborative. For this purpose, the teacher 
should be part of this environment, proposing actions that encourage hybrid teaching, the maker culture, the discussion of complex problems that have interdisciplinary and/or transdisciplinary themes that require the participation of everyone in the search for solutions, in stimulation of leaders, developing or improving their soft skills, since this environment will be experienced, in practice, by these future professionals at their workstations, with the Institution and teachers simulating the modern corporate environment in a more realistic way.

Table 2: Main characteristics that are expected in the training of professionals for an "Industry 4.0":

\begin{tabular}{|c|c|}
\hline Characteristics/Skills & Definition \\
\hline Interdisciplinarity & $\begin{array}{l}\text { It is a concept that intersects the contents of two or more } \\
\text { disciplines, allowing the student to build a broader view of } \\
\text { the subjects studied, favoring a critical analysis of the } \\
\text { different approaches to the same subject. }\end{array}$ \\
\hline Transdisciplinarity & $\begin{array}{l}\text { It is the ability to produce an interaction between disciplines, } \\
\text { not only restricting itself to the disciplinary content, but } \\
\text { proposing a dialogue between fields of knowledge, seeking to } \\
\text { reach and change the subject's perception, cognition or } \\
\text { behavior. }\end{array}$ \\
\hline Maker Culture & $\begin{array}{l}\text { The search for creative, innovative, sustainable and } \\
\text { technological solutions ended up providing greater visibility } \\
\text { to this terminology. This is an evolution of the DIY (Do It } \\
\text { Yourself) concept, in other words, do it yourself. Through } \\
\text { proper knowledge, people, with the right tools, can create } \\
\text { their own solutions. It's learning by doing. }\end{array}$ \\
\hline Artificial Intelligence & $\begin{array}{l}\text { A set of software that allows computers to perform functions } \\
\text { such as perceiving meaning in written or spoken language, } \\
\text { learning, recognizing facial expressions, and so on. }\end{array}$ \\
\hline $\begin{array}{l}\text { Collaborative } \\
\text { Environment }\end{array}$ & $\begin{array}{l}\text { Environment where all participants collaborate with each } \\
\text { other in the construction of certain knowledge. This } \\
\text { environment has a repository where everyone can actively } \\
\text { build. }\end{array}$ \\
\hline $\begin{array}{ll}\text { Digital } & \text { Teaching } \\
\text { Material } & \end{array}$ & $\begin{array}{l}\text { It is the teaching materials that make use of digital media to } \\
\text { portray their content. They can interact with students, } \\
\text { making it easier to understand certain topics or themes. }\end{array}$ \\
\hline Learning IoT & $\begin{array}{l}\text { Allows direct and continuous interaction between students } \\
\text { and teachers via mobile devices, potential for mobile and } \\
\text { ubiquitous learning. }\end{array}$ \\
\hline $\begin{array}{l}\text { Computational } \\
\text { thinking, technological } \\
\text { design and } \\
\text { programming. }\end{array}$ & $\begin{array}{l}\text { Computational thinking is about formulating problems } \\
\text { and solutions represented in such a way that they can be } \\
\text { performed by humans and/or computers. The activities } \\
\text { developed in this perspective are intended to contribute } \\
\text { to the construction of logical thinking and pattern } \\
\text { recognition skills. }\end{array}$ \\
\hline $\begin{array}{l}\text { Knowledge } \\
\text { Management }\end{array}$ & $\begin{array}{l}\text { Collective and collaborative form of repositories with the } \\
\text { purpose of managing the knowledge created and shared, } \\
\text { aiming at maintaining the information, accessible to all who } \\
\text { do not need it. }\end{array}$ \\
\hline $\begin{array}{l}\text { Reasoning, Problem } \\
\text { Solving and Ideation }\end{array}$ & $\begin{array}{l}\text { Within the Education } 4.0 \text { environment, the student is } \\
\text { encouraged by the teacher to seek answers in order to solve }\end{array}$ \\
\hline
\end{tabular}




\begin{tabular}{|c|c|}
\hline & $\begin{array}{l}\text { problems, no longer being a passive element, just absorbing } \\
\text { content, becoming an active element in the construction of } \\
\text { existing problems. }\end{array}$ \\
\hline Team Work & $\begin{array}{l}\text { Group work, collaboratively, so that everyone can } \\
\text { collaborate on developing solutions. }\end{array}$ \\
\hline Soft Skills & $\begin{array}{l}\text { These are the personal, mental, social and emotional } \\
\text { capacities that people acquire throughout their lives. Your } \\
\text { personal experiences and experiences. In short, it's your } \\
\text { behavioral skills. }\end{array}$ \\
\hline $\begin{array}{l}\text { Creativity, originality } \\
\text { and iniative }\end{array}$ & $\begin{array}{l}\text { It is a person's ability to create, compose, invent, innovate in } \\
\text { the environment in which they work, live or study. }\end{array}$ \\
\hline Project-Based Lerning & $\begin{array}{l}\text { Students hone their skills using them in real-world problem } \\
\text { situations from specific projects. }\end{array}$ \\
\hline $\begin{array}{l}\text { analytical thinking and } \\
\text { innovation }\end{array}$ & $\begin{array}{l}\text { It becomes a way of thinking with the objective of } \\
\text { explaining things by decomposing them into simpler parts, } \\
\text { which are more easily explained or solved, and once } \\
\text { understood, they make it possible to understand the whole. }\end{array}$ \\
\hline $\begin{array}{l}\text { Active Learning and } \\
\text { Learning Strategies }\end{array}$ & $\begin{array}{l}\text { It is a technical term for a set of pedagogical practices that } \\
\text { address the issue of student learning from a different } \\
\text { perspective than classical learning techniques. Active } \\
\text { learning is a teaching methodology that encourages student } \\
\text { autonomy in their own education. }\end{array}$ \\
\hline critical thinking & $\begin{array}{l}\text { It takes on the specific ability to correctly assess the } \\
\text { arguments made by others and also to construct solid and } \\
\text { consistent arguments on its own. }\end{array}$ \\
\hline $\begin{array}{l}\text { Solving } \\
\text { problems }\end{array}$ & $\begin{array}{l}\text { It is a condition that can be resolved through analysis, } \\
\text { dedication and training of those involved. Complex problems } \\
\text { are those that: Never happened before; They have no known } \\
\text { solutions or a single, perfect solution; They have one or more } \\
\text { variables that make them complex, and they are all } \\
\text { interrelated. The main input for solving a complex problem } \\
\text { is to rely on the participation of people who are capable of } \\
\text { thinking and outlining assertive paths to resolve these } \\
\text { conflicts. }\end{array}$ \\
\hline
\end{tabular}

Source: Adapted from Fuhr (2019), Rasquilha e Veras (2019) and Author

Given the above, we propose in Figure 4, a flow of actions that can be used by teachers to prepare a class that can be applied to any type of course, but that exposes the student to some decision variables, stressors, etc. 
Figure 4: Action Flow

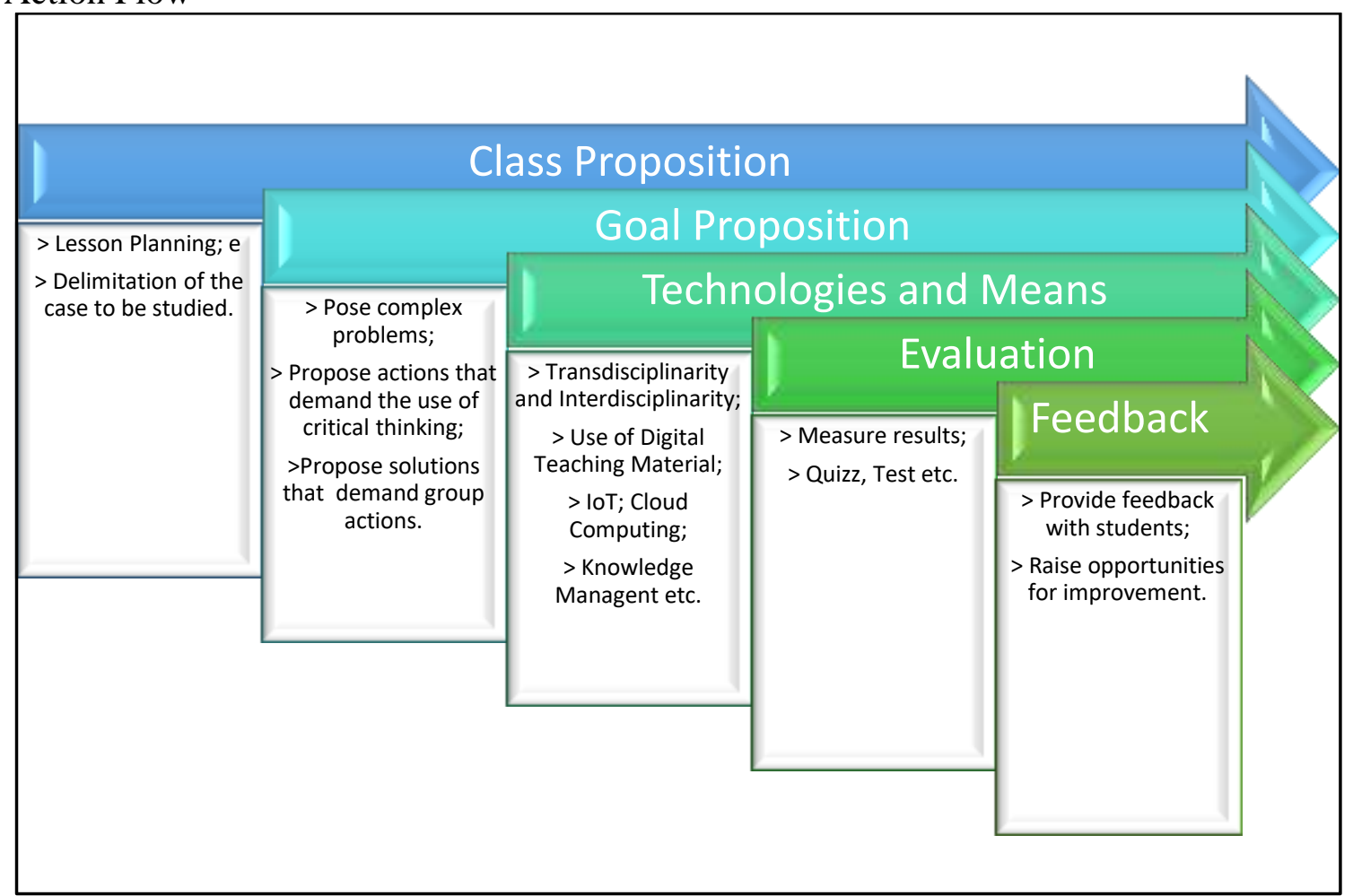

Source: The Author.

The process starts with a lesson proposal. At this point, the teacher will plan his class, evaluating the case to be studied and its limits, that is, to what level the topic is intended to be addressed. The next step involves proposing the objectives and actions that students should perform. It is time to delve into the topic, checking which stressors can be used, causing discomfort in students in such a way that they perform the expected behaviors, such as the group meeting, the emergence of leaders and the use of critical thinking in the presentation arguments to support their positions and solve the complex problems presented. It is important that the teacher makes use of tools, technologies and situations that allow the use of digital teaching materials, IoT, cloud computing. Proposing themes based on themes that allow for interdisciplinarity and/or transdisciplinarity, in order to reach a wider range of subjects, making connections and linking ideas and solutions. After the students arrive at the solutions, it is important for the teacher to assess the group's grasp of knowledge, thus, it is essential to propose an assessment. A Quizz is a dynamic, fast, most of the time fun and functional way, used to verify a learning experience. Finally, providing feedback is essential to rectify or ratify knowledge, actions, behaviors, standards, etc.

Next, we will report the application of this model in two different disciplines. The first, in a face-to-face class of Educational Management Fundamentals, and the other, in a distance learning class, Transport and Distribution.

\subsection{Application of the method in a discipline of Fundamentals of Educational Management}

Next, we will report on the application of this model in the Fundamentals of Educational Management subject, at the Brazilian Army Personnel Studies Center, which is stratified in Figure 5. 


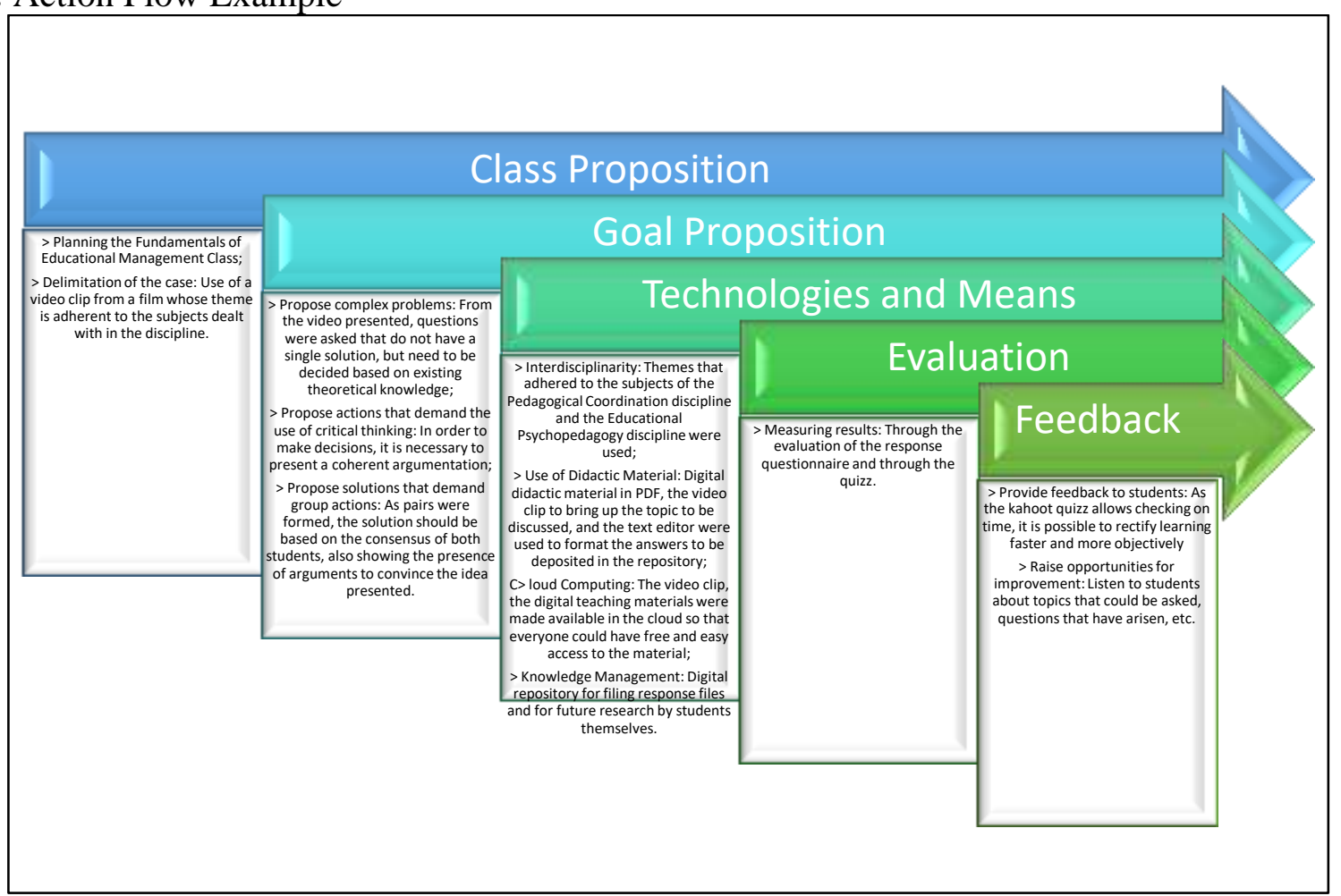

Source: The author

This subject is offered to the Educational Psychopedagogy and Pedagogical Coordination Courses. Although the focus of the course is on the pedagogical area, the discipline has a managerial fulcrum which, in a macro view, allows the use of systematics in any course that has a management view.

In preparing this class, the formation of pairs of students was proposed, consisting of one student from each course. For that, a film was compiled whose theme would support the questions proposed in the evaluation, based on the creation of a clip with passages that would be coherent with the subjects presented in the classroom, delimiting the case to be studied by the students. The choice of movie passages presented situations that met the students' need to take a stand and present convincing arguments for decision-making. As the subject contained students from two different courses, interdisciplinarity was used to cross-reference issues relating to Pedagogical Coordination and Educational Psychopedagogy. The material made available was completely digital, using the cloud to store it and make it available to everyone. After everyone has watched the video clip, students should make their considerations, in the previously established pairs, answer the questionnaire digitally and make it available in a repository, in line with what the management theme prescribes. of knowledge. Finally, in the next class, a correction of learning was carried out with the approach of themes with the greatest number of wrong answers to make course corrections.

\subsection{Application of the method in a Transport and Distribution discipline}

The model was also applied in the form of distance learning, in the discipline of Transport and Distribution, in the Postgraduate Course in Logistics of a traditional Educational Foundation existing in Brazil, with offices in Rio de Janeiro and São Paulo and international coverage, in virtue of its online course offering. Next, we will proceed to the report on the application of this model, which is stratified in Figure 6 . This subject is offered, in the distance learning modality, to the Postgraduate Course in Logistics. 
Figure 6: Example of Action Flow for the Discipline of Transport and Distribution

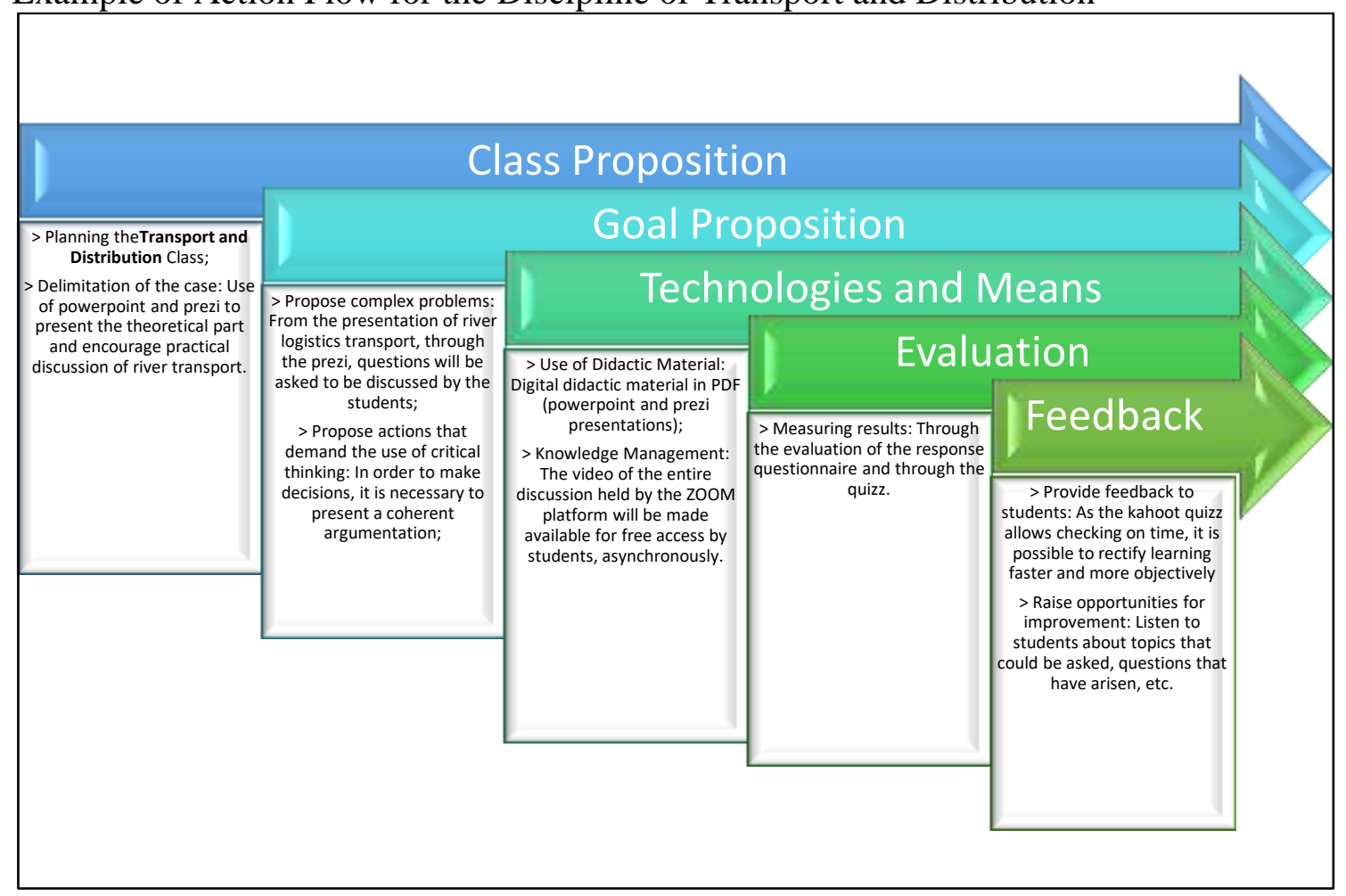

Source: The autor

This course is divided into four modules and, every week, there is a synchronous meeting, using the ZOOM tool. In the preparation of the class, referring to Module 2, it was initially proposed a theoretical presentation of the subjects concerning that module, which dealt with logistical modalities, logistical operators and vehicle routing. Inherent in the presentation of concepts, practical cases were presented as examples, in order to ratify theory with practice. At the end, a teaching case was presented, created by the professor, which narrates his personal experience in the realization of the river waterway logistics modal in the Brazilian Amazon region. During this procedure, some questions about decision making were asked. At the end, a Quizz was performed, using the Kahoot tool, where students answered some questions and were ranked and valued. Finally, a rectification of learning was carried out with the approach of themes with a greater amount of wrong answers in order to carry out course corrections.

\section{Conclusion}

This study sought to highlight the importance and need for qualified teachers who are knowledgeable about the technologies used in the mainstay of the 4th Industrial Revolution. In addition, it was concerned with presenting a flow of actions in the preparation of a class with characteristics of the 4.0 education tools. The idea was to propose a standard systematic that could be used in any 4.0 educational environment for areas such as industry, logistics and management 4.0.

Guiding teaching actions to prepare professionals who will work in connected environments and with characteristics inherent to the 4.0 industry is no longer a fad to become a pressing need, since many of the professionals are digital natives and have skills aimed at this digital universe.

This was a proposal that worked quite effectively for the fundamentals of educational management and transport and distribution disciplines. In this way, we believe that the flow presented will serve as support for the various disciplines that include actions aimed at systematic education 4.0.

Finally, we hope that other disciplines seek to follow the theme and experiment with it in order to ratify the proposal and present opportunities for improvement in order to continuously improve.

\section{Data Availability Statement (DAS)}


Raw data were generated at Centro de Ensino de Pessoal do Exército Brasileiro and Fundação Getulio Vargas. Derived data supporting the findings of this study are available from the corresponding author [Pinto, C. A. S.] on request.

\section{References}

1. ACIOLI, C; SCAVARDA, A; REIS, A. (2021). Applying Industry 4.0 technologies in the COVID-19 sustainable chains. International Journal of Productivity and Performance Management, Vol. 70 No. 5, pp. 988-1016. DOI: $10.1108 / \mathrm{IJPPM}-03-2020-0137$.

2. BAHRIN, M. A. K; OTHMAN, M.F; AZLI, N. N; TALIB, M. F. (2016). Industry 4.0: A review on industrial automation and robotics. J. Teknol, 78, 137-143. DOI: 10.11113/jt.v78.9285

3. BITKOM; VDMA; ZVI. (2016). Implementation strategy industrie 4.0: report on the results of the industrie 4.0 platform. Frankfurt, Alemanha, 2016. Available at: https://www.bitkom.org/Bitkom/Publikationen/Implementation-Strategy-Industrie-40-Report-on-theresults-of-the-Industrie-40-Platform.html. Access on March18, 2021.

4. BOWERSOX, D. J.; CLOSS, D. J.; COOPER, M. B.; BOWERSON, J. C. (2014) Gestão Logística da Cadeia de Suprimentos $4^{\text {th }}$. .ed, AMGH Editora Ltda.

5. CARVALHO NETO, C. Z. (2019). Educação 4.0: Princípios e práticas de inovação em gestão e docência. $2^{\text {th }}$.ed. São Paulo: Laborciência editora.

6. CHAO, H. (2005). The non-specific intelligent guided-view system based on RFID technology. In: 19th International Conference on Advanced Information Networking and Applications (AINA'05) Volume 1 (AINA papers). IEEE, 2005. p. 580-585. DOI: 10.1109/AINA.2005.327

7. DECOTIGNIE, J.D. (2009). The many faces of industrial ethernet [past and present]. IEEE Ind. Electron. Mag.3, 8-19. DOI: 10.1109/MIE.2009.932171.

8. BUNDESMINISTERIUM FÜR BILDUNG UND FORSCHUNG (BMBF). (2014). Industrie 4.0. Innovationen für die Produktion von Morgen, Alemanha. Available on: https://www.bmbf.de/upload_filestore/pub/Industrie_4.0.pdf.

9. FANG, L., XUE, G., LYU, F., SHENG, H., ZOU, F., LI, M. (2018). Intelligent large-scale ap control with remarkable energy saving in campus wifi system. In 2018 IEEE $24^{\text {th }}$ International Conference on Parallel and Distributed Systems (ICPADS), pages 69-76.IEEE. DOI: 10.1109/PADSW.2018.8645048.

10. FUERTES, Juan José; PRADA, Miguel Ángel; RODRÍGUEZ-OSSORIO, José Ramon; GONZÁLEZHERBÓN, Raúl; PÉREZ, Daniel; DOMÍNGUEZ, Manuel. "Environment for Education on Industry 4.0," in IEEE Access, vol. 9, pp. 144395-144405, 2021, DOI: 10.1109/ACCESS.2021.3120517.

11. GIANNAKIS, M., LOUIS, M. (2016). A multi-agent based system with big data processing for enhanced supply chain agility. Journal of Enterprise Information Management, 29(5), 706-727. DOI:10.1108/JEIM-062015-0050

12. GRODOTZKI, Joshua; ORTELT, Tobias R; TEKKAYA, A. Erman. Remote and Virtual Labs for Engineering Education 4.0: Achievements of the ELLI project at the TU Dortmund University, Procedia Manufacturing, Volume 26, 2018, Pages 1349-1360, https://doi.org/10.1016/j.promfg.2018.07.126.

13. HERADIO, Ruben; CUBILLO, Luis de la Torre; DORMIDO, S. (2016). Virtual and remote labs in control education: A survey. Annual Reviews in Control. 42. 1-10. DOI: 10.1016/j.arcontrol.2016.08.001.

14. HERNÁNDEZ DE MENÉNDEZ, Marcela; VALEJO JUNIOR, Antonio; TUDÓN-MARTÍNEZ, Juan; HERNANDEZ-ALCANTARA, Diana; MORALES-MENENDEZ, Ruben. (2019). Active learning in engineering education. A review of fundamentals, best practices and experiences. International Journal on Interactive Design and Manufacturing (IJIDeM). 13. 10.1007/s12008-019-00557-8.

15. HIMMETOGLU, B; AYDUG, D; BAYRAK, C. (2020). Education 4.0: defining the teacher, the student, and the school manager aspects of the revolution. Turkish Online Journal of Distance Education-TOJDE. IODLSpecial Issue Article 2. July 2020. Available at: http://hdl.handle.net/20.500.12424/3960701.

16. ILIE-ZUDOR, E.; KEMÉNY, Z.; EKÁRT, A.; BUCKINGHAM, D.; MONOSTORI, L. (2014). A solution for information management in logistics operations of modern manufacturing chains. Procedia CIRP 25. DOI: 10.1016/j.procir.2014.10.047 
17. KACHE, F., SEURING, S. (2017). Challenges and opportunities of digital information at the intersection of big data analytics and supply chain management. International Journal of Operations \& Production Management, 37(1), 10-36. DOI: 10.1108/IJOPM-02-2015-0078

18. KHATIB, E. J.; BARCO, R. (2021). "Optimization of 5G Networks for Smart Logistics" Energies 14, no. 6 : 1758. DOI: $10.3390 /$ en14061758.

19. LEITOLD, D.; VATHY-FOGARASSY, A.; VARGA, K.; ABONYI, J. (2018). RFID-based task time analysis for shop floor optimization. In: 2018 IEEE International Conference on Future IoT Technologies (Future IoT). IEEE, 2018. p. 1-6. DOI: 10.1109/FIOT.2018.8325587

20. MUNSHI, A. A; MOHAMED, Y. A. R. I. (2017). Big data framework for analytics in smart grids. Electric Power Systems Research, 151, 369-380. DOI: 10.1016/j.epsr.2017.06.006.

21. PINTO, C. A. S. (2019). A gestão do conhecimento e a inteligência colaborativa em ambientes de aprendizagem: um estudo a partir da oficina de robótica educacional no Colégio Militar do Rio de Janeiro / Carlos Alberto Schettini Pinto. Dissertação (Mestrado) Centro Federal de Educação Tecnológica Celso Suckow da Fonseca.

22. PINTO, C. A. S; REIS, A. da C. BRAGA, M. (2020) The supply chain as part of knowledge management in organizational environments. Int. J. Logistics System and Management, v.36, n.3, 2020. DOI:10.1504/IJLSM.2020.108693

23. PINTO, C.A.S. (2020). Knowledge management as a support for supply chain logistics planning in pandemic cases. Brazilian Journal of Operations \& Production Management, Vol. 17, No. 03, e2020970. DOI:10.14488/BJOPM.2020.033.

24. RAO, S.K.; PRASAD, R. (2018). Impact of 5G technologies on industry 4.0. Wirel. Pers. Commun.100, 145159. DOI: $10.1007 / \mathrm{s} 11277-018-5615-7$

25. SATOH, I. (2004). A mobile agent-based framework for location-based services. In: 2004 IEEE International Conference on Communications (IEEE Cat. No. 04CH37577). IEEE, 2004. p. 1355-1359.

26. SEGS. (2021). Logística 4.0: o caminho para a digitalização e produtividade. April 16, 2021. Available at: https://www.segs.com.br/info-ti/285441-logistica-4-0-o-caminho-para-a-digitalizacao-e-produtividade.

27. SISINNI, E.; SAIFULLAH, A.; HAN, S.; JENNEHAG, U.; GIDLUND, M. (2018). Industrial internet of things: Challenges, opportunities, and directions. IEEE Trans. Ind. Inform. 14, 4724-4734. DOI: 10.1109/TII.2018.2852491

28. SRINIVASAN, R; SWINK, M. (2018). An investigation of visibility and flexibility as complements to supply chain analytics: An organizational information processing theory perspective. Production and Operations Management, 27(10), 1849-1867. DOI:10.1111/poms.12746

29. TAKEUCHI, H; NONAKA, I. Gestão do Conhecimento. Porto Alegre: Bookman. 2008.

30. TRSTENJAK, M. e COSIC, P. (2017). "Process planning in Industry 4.0 environment", Procedia Manufacturing, vol. 11, junho, pp. 1744-1750. DOI: 10.1016/j.promfg.2017.07.303

31. WEN, J.; HE, L.; ZHU, F. (2018). Swarm robotic control and communications: imminent challenges for the next generation of intelligent logistics. IEEE Commun. Mag. 56, 102-107. DOI: 10.1109/MCOM.2018.1700544

32. WINKELHAUS, S; GROSSE, E. (2020). Logistics 4.0: a systematic review towards a new logistics system. International Journal of Production Research, 58 (1): 18-43. DOI: $10.1080 / 00207543.2019 .1612964$

33. ZHAO, R., LIU, Y., ZHANG, N., HUANG, T. (2017). An optimization model for green supply chain management by using a big data analytic approach. Journal of Cleaner Production, 142, 1085-1097. DOI: 10.1016/j.jclepro.2016.03.006

34. ZHONG, R. Y., NEWMAN, S. T., HUANG, G. Q., LAN, S. (2016). Big data for supply chain management in the service and manufacturing sectors: Challenges, opportunities, and future perspectives. Computers \& Industrial Engineering, 101, 572-591. DOI:10.1016/j.cie.2016.07.013 